\title{
Dental Status of Institutionalized Persons with Special Needs who Live in Special Institution "Srce u jabuci" in Pancevo
}

\author{
Tatjana Savić-Stanković, Milica Jovanović-Medojević, Slavoljub Živković \\ Clinic for Restorative Dentistry and Endodontics, School of Dentistry, University of Belgrade, Belgrade, Serbia
}

\begin{abstract}
SUMMARY
Introduction Dental status of most people with special needs is not satisfactory. Many of them are edentulous or toothless, with acute extensive caries lesions present, high DMFT index and severe periodontal disease. The objective of this study was to examine the dental status of mentally impaired persons who live in the special institution "Srce u jabuci" in Pancevo.

Material and Methods Clinical examination was performed on 114 institutionalized patients (68 male and 46 female), age 22 to 71 years. Patients were divided in two groups; the first group consisted of 71 persons who had a moderate mental disorder (F71), while the second group included 43 respondents with severe mental retardation (F72). Oral examination revealed: the number of present teeth, caries lesions, the presence of restorations, the number of extracted teeth, the presence of residual roots, fractures and the presence and number of fixed restorations.

Results The mean DMFT of total examined teeth was 20.33 \pm 7.63 . The greatest percentage found for extracted teeth (63.76\%): in the first group $63.23 \%$, and in the second $64.06 \%$. The percentage of teeth that had caries lesions of all examined teeth was $33.48 \%$, while the lowest percentage was for restored teeth $(2.76 \%)$. In majority of examined people, initial caries, deep caries, or tooth with the exposed pulp (K1 - 51.74\% K2 - 40.35\%, K3 - 51.75\%) were not found. A high percentage of examined people had more than 10 extracted teeth (52.63\%). Most of them did not have any restoration in the mouth (81\%) and only three persons had fixed denture.

Conclusion Dental status of institutionalized mentally impaired persons showed high prevalence of extracted teeth, significant presence of carious lesions and small percentage of restored teeth with inadequate oral hygiene.
\end{abstract}

Keywords: persons with special needs; caries; extraction; restoration

\section{INTRODUCTION}

If health is considered as the state of complete physical, mental and social well-being and not merely the absence of disease and disability (world widely accepted definition of health) [1], persons having mental impairment are not completely healthy because the oral health is often neglected. Mentally impaired persons, usually institutionalized because of impaired reasoning and understanding and their dependence, require a special attention and care in every part of life especially in regards to the oral health care. Unfortunately, most of these people are often edentulous or toothless, with the presence of extensive acute caries lesions, a high DMFT index and severe periodontal diseases [2]. This problem accumulates due to many factors, the most important is that these institutions do not have dentists who would take care of their oral health. Also, many dentists have prejudices about difficulties in providing dental services to the patients having mental retardation. Additional problem is that these people often refuse help to restore their teeth, and eventually when they see a dentist, interventions are urgent and painful.

Oral health affects daily functioning and quality of life of mentally disabled persons, and often is further compro- mised by the presence of other systemic diseases [3]. The side effects of different therapeutic procedures and medications often given to these patients increase the risk for oral diseases due to reduced salivation, gingival inflammation, alveolar bone resorption and tooth mobility [4]. We should not exclude the fact that most of these people receive analgesic therapy, and pain as the warning factor that something is happening with the teeth is frequently eliminated.

One of the possibilities to treat mentally disabled persons (especially in most severe cases) is to perform dental procedures under general anesthesia. This procedure is much easier for both, the patient and the therapist and enables regular, detailed and complete dental intervention [5].

The level of oral health of mentally disabled people can be improved by proper approach, implementation of preventive procedures, and continuous monitoring of their oral condition and health. By training the support staff and caregivers how to efficiently perform oral hygiene, oral health in this population could be successfully improved. Epidemiological studies that have the aim to determine the level of oral health in population, preventive measures, functioning and effectiveness of dental health services are 
mainly conducted in younger groups. This type of research in older population, including people with special needs, is extremely rare and literature data is scarce.

The aim of this study was to determine soft tissue and dental status of institutionalized mentally retarded persons as well as the need for their dental treatment.

\section{MATERIAL AND METHODS}

Clinical examination was performed on 114 mentally handicapped patients who live in institution for patients with special needs "Srce u jabuci" in Pancevo (68 male and 46 female), age 22 to 71 years. Based on the degree of mental impairment and according to the International Classification of Diseases (ICD-10), all patients were divided into two groups. The first group consisted of 71 patients having moderate mental disorder (F71), and the second group included 43 patients with severe retardation (F72).

Clinical examination was performed using dental mirror, dental probe, proximal and periodontal probe.
For each patient, the number of present teeth, caries lesion presence, restorations (amalgam and aesthetic), the number of extracted teeth, the presence of residual roots $(\mathrm{R})$, fractures $(\mathrm{F})$ or fixed dentures $(\mathrm{FD})$ was registered in dental record.

Caries prevalence was determined using the DMFT index and its components as following: $\mathrm{K} 1$ - initial caries (caries in enamel), K2 - deep caries (caries in dentin), $\mathrm{K} 3$ - exposed pulp, $\mathrm{R}$ - restorations, $\mathrm{E}$ - extracted teeth. Residual roots and fractures were analyzed as a subcomponent of caries.

\section{RESULTS}

The mean DMFT for the total examined teeth was $20.33 \pm 7.63$, and mean DMFT for the first group was 19.96 \pm 7.11 and 20.95 \pm 8.47 in the second group (Table 1).

By analyzing the components of DMFT, statistically significant difference was found between the number of extracted teeth and teeth having caries or restored teeth

Table 1. DMFT index and its components in examined patients

Tabela 1. Vrednosti KEP indeksa i njegovih komponenti kod pregledanih pacijenata

\begin{tabular}{|c|c|c|c|c|c|c|c|}
\hline \multirow{2}{*}{$\begin{array}{l}\text { Level of mental } \\
\text { impairment } \\
\text { Stepen mentalne } \\
\text { retardacije }\end{array}$} & \multirow{2}{*}{$\begin{array}{l}\text { DMFT } \\
\text { KEP }\end{array}$} & \multicolumn{4}{|c|}{$\begin{array}{l}\text { Caries (\%) } \\
\text { Karijes (\%) }\end{array}$} & \multirow{2}{*}{$\begin{array}{l}\text { Extracted teeth (\%) } \\
\text { Ekstrahovani zubi (\%) }\end{array}$} & \multirow{2}{*}{$\begin{array}{l}\text { Restored teeth (\%) } \\
\text { Plombirani zubi (\%) }\end{array}$} \\
\hline & & $\begin{array}{c}\text { Total } \\
\text { Ukupno }\end{array}$ & $K(1,2,3)$ & $\begin{array}{l}\text { Radix } \\
\text { Koren }\end{array}$ & $\begin{array}{l}\text { Fracture } \\
\text { Fraktura }\end{array}$ & & \\
\hline F71 & $19.96 \pm 7.11$ & 33.79 & 18.13 & 14.68 & 0.98 & 63.23 & 2.96 \\
\hline F72 & $20.95 \pm 8.47$ & 32.96 & 14.87 & 14.76 & 3.33 & 64.06 & 2.44 \\
\hline All / Svi & $20.33 \pm 7.63$ & \multicolumn{4}{|c|}{33.48} & 63.76 & 2.76 \\
\hline
\end{tabular}

Table 2. Distribution of extracted teeth in examined patients

Tabela 2. Distribucija ekstrahovanih zuba kod pregledanih pacijenata

\begin{tabular}{|c|c|c|c|c|c|c|}
\hline \multirow{3}{*}{$\begin{array}{l}\text { Level of mental impairment } \\
\text { Stepen mentalne retardacije }\end{array}$} & \multicolumn{6}{|c|}{ Number of teeth (\%) / Broj zuba (\%) } \\
\hline & \multirow{2}{*}{$\mathbf{0}$} & \multirow{2}{*}{$1-5$} & \multirow{2}{*}{$<10$} & \multicolumn{3}{|c|}{$>10$} \\
\hline & & & & Total / Ukupno & $10-20$ & $>20$ \\
\hline F71 & 2.82 & 18.31 & 25.35 & 52.11 & 30.99 & 21.13 \\
\hline F72 & 2.33 & 13.95 & 27.91 & 53.49 & 32.56 & 20.93 \\
\hline All / Svi & 2.63 & 16.67 & 26.32 & 52.63 & 31.58 & 21.05 \\
\hline
\end{tabular}

Table 3. Distribution of initial caries $(K 1)$ in examined patients

Tabela 3. Distribucija inicijalnog karijesa (K1) kod pregledanih pacijenata

\begin{tabular}{|c|c|c|c|c|c|c|c|c|c|}
\hline \multirow{2}{*}{$\begin{array}{l}\text { Level of mental impairment } \\
\text { Stepen mentalne retardacije }\end{array}$} & \multicolumn{9}{|c|}{ Number of teeth (\%) / Broj zuba (\%) } \\
\hline & 0 & 1 & 2 & 3 & 4 & 5 & 6 & 7 & Total / Ukupno \\
\hline F71 & 52.11 & 15.5 & 18.31 & 8.45 & 2.82 & 1.41 & 1.41 & 0 & 100 \\
\hline F72 & 51.16 & 23.26 & 11.63 & 6.98 & 2.32 & 0 & 2.32 & 2.32 & 100 \\
\hline All / Svi & 51.74 & 18.79 & 15.65 & 7.89 & 2.63 & 0.87 & 1.75 & 0.87 & 100 \\
\hline
\end{tabular}

Table 4. Distribution of deep caries (K2) in examined patients

Tabela 4. Distribucija dubokog karijesa (K2) kod pregledanih pacijenata

\begin{tabular}{|c|c|c|c|c|c|c|c|c|c|}
\hline \multirow{2}{*}{$\begin{array}{l}\text { Level of mental impairment } \\
\text { Stepen mentalne retardacije }\end{array}$} & \multicolumn{9}{|c|}{ Number of teeth (\%) / Broj zuba (\%) } \\
\hline & 0 & 1 & 2 & 3 & 4 & 5 & 6 & 7 & Total / Ukupno \\
\hline F71 & 29.58 & 29.58 & 18.31 & 9.86 & 5.63 & 5.63 & 0 & 0 & 100 \\
\hline F72 & 58.14 & 13.95 & 13.95 & 9.30 & 0 & 0 & 0 & 4.65 & 100 \\
\hline All / Svi & 40.35 & 23.68 & 16.67 & 9.65 & 3.51 & 3.51 & 0 & 1.75 & 100 \\
\hline
\end{tabular}

Table 5. Distribution of exposed pulp (K3) in examined patients

Tabela 5. Distribucija eksponirane pulpe (K3) kod pregledanih pacijenata

\begin{tabular}{|c|c|c|c|c|c|c|c|c|c|}
\hline \multirow{2}{*}{$\begin{array}{l}\text { Level of mental impairment } \\
\text { Stepen mentalne retardacije }\end{array}$} & \multicolumn{9}{|c|}{ Number of teeth (\%) / Broj zuba (\%) } \\
\hline & $\mathbf{0}$ & 1 & 2 & 3 & 4 & 5 & 6 & 7 & Total / Ukupno \\
\hline F71 & 49.30 & 16.90 & 14.08 & 15.50 & 4.23 & 0 & 0 & 0 & 100 \\
\hline F72 & 55.81 & 18.60 & 13.95 & 2.33 & 2.33 & 4.65 & 0 & 2.33 & 100 \\
\hline All / Svi & 51.75 & 17.54 & 14.04 & 10.53 & 3.51 & 1.75 & 0 & 0.88 & 100 \\
\hline
\end{tabular}


$(t=2.06 ; p<0.005)$. Statistically significant difference was not found in the number of initial caries (K1), deep caries (K2) and teeth with the exposed pulp (K3) (Table 1).

Table 2 shows the percentage of extracted teeth in examined persons. The greatest number of patients had more than 10 extracted teeth (52.63\%). Of these $21.05 \%$ patients had more than 20 teeth extracted. Only $2.63 \%$ of people had none tooth extracted. In the first group, more than 10 extracted teeth had $52.11 \%$ of people, while in the second group this percentage was $53.49 \%$.

Table 3 shows the distribution of initial caries (K1) in examined patients. The majority of patients did not have initial decay K1 (51.74\%). A similar finding was also in the first (52.11\%) and the second group of respondents $(51.16 \%)$.

Table 4 presents the distribution of deep caries (K2). The highest percentage of patients had deep caries K2 (40.35\%). In the first group, the equal number of patients did not have tooth decay and had deep caries K2 (29.58\%). In the second group, the highest percentage of treated patients did not have any deep decay K2 (58.14\%).

Table 5 shows the distribution of exposed pulp K3 in all examined patients. Most of these people did not have pulp exposure (51.75\%), and similar results were observed in first (49.30\%) and second group (55.81\%).

The highest percentage of examined people had no restoration $(81 \%)$. One restoration had $6 \%$ of patients, two to three fillings $9 \%$ of examined persons, while more than 4 restorations had only $4 \%$ of treated patients.

Most of patients had no fixed dentures (111). Only one patient had one fixed restoration, while two patients had two fixed restorations.

\section{DISCUSSION}

Poor oral health of mentally impaired people is mostly expected due to severe general condition of these patients as well as often neglecting of this aspect of their health. These people are not able to independently take care of oral hygiene because of their disability, which by the time affects their oral health in general. The problem with oral hygiene is often the consequence of their frailty and sometimes absolute lack of muscle coordination or inability to understand and follow the instructions and advice regarding the preventive measures [6]. The proper daily oral hygiene is one of the most important factors in preventing oral diseases, and the absence of oral hygiene leads to the initiation and rapid progression of oral disease in institutionalized people $[7,8]$.

DMFT index is one of the most commonly used indices in epidemiological studies in order to present the teeth condition, specifically the incidence of teeth affected by caries, extracted and restored teeth $[9,10]$. The results of this study showed the high mean DMFT index (20.95 \pm 8.47$)$. Such high values can be interpreted primarily by generally poor condition of these patients, not just as consequence of disability and dependence, but also as the fact that there is no adequate dental care service and the treatment is not provided promptly.
People having severe degree of psycho-physiological disorders in addition to mental impairment often have severe motor disorders; in most cases they are hardly moving and even completely immobile [6]. The difference in DMFT values between the first and second group was not significant in the current study because the institutionalized people (even those with higher levels of intellectual disability) are better socialized and much more independent than those who do not live in such institutions. Data from the literature showed that the value DMFT of these patients in the US is 13.6 and 15.85 in West European countries [11], which clearly indicate that the development of the country or region can be one of the main factors for oral health. Unfortunately, there is little available data about research in this field in the region, Europe and world and it is difficult to compare this result with findings of similar studies.

The results of this research and the value of DMFT of 24.4 are partially in agreement with the findings for psychiatric patients in "Dr. Laza Lazarevic" hospital, although mental state of these patients is not similar [12]. Ramon et al. [13], Velasco et al. [14] and Angelillo et al [15]. also found similar values of DMFT in psychiatric patients (26.74, 24.99 and 15.5). The results of Kumar et al. [16] who found the mean DMFT of 0.92 were significantly different from the current study and can be explained by the fact that his results referred to the patients who used fluoridated drinking water.

The results of the current study are also different from Rodríguez Vázquez et al. [17] findings. They found the mean DMFT of 3.97 in patients with Down syndrome, 6.56 in patients with cerebral palsy, and 7.36 in patients with idiopathic developmental disorders. Such a low value of the DMFT, the authors explained by the fact that hospitalized patients had a diet under constant supervision including the sugar level control in food they consumed.

The analysis of DMFT in the current study indicates that the greatest percentage was for extracted teeth. Absence of pain, as the result of continuous analgesic medication, difficulties in co-operation, absence of permanent dental supervision, and generally "late" interventions are main reasons for high number of extracted teeth. The same reasons explain also the fact that the majority of patients had no initial caries, deep caries, as well as the pulp exposure. Fast and progressive carious lesions in patients with inadequate oral hygiene rapidly lead to tooth extraction. The lowest percentage of patients had restored teeth. This is consistent with low percentage of carious lesions, difficulties in cooperation of these patients, but also lack of timely dental intervention and concern about their oral health [18].

Of 114 examined patients, only three of them had fixed dentures. This information indicates that the complex dental interventions (requiring more visits and cooperation with patients) can be performed in special institution (office) only, with increased attention and involvement of staff and family members. With adequate and joint effort of everyone who belongs to the system of care for a person with special needs, prosthetic rehabilitation and implants are possible options [19]. 
Serbia is one of a few countries in the world that do not have complete data about the state of oral health of its population [20]. The recent transformation of the health care system in most Balkan countries, especially those undergoing political and economic transition, excluded dental health care almost completely from the system of health care. Moving dental care to the private sector caused numerous problems; among them are unavailability and loss of access to information about oral health of general population, as well as mentally impaired population. To solve the problem, Serbia adopted the National Program for Prevention of Oral Diseases in early 2009 [21].

International literature consistently indicates poor condition of the mouth and teeth, high number of extracted teeth and small number of restorations as dental status of mentally impaired persons $[22,23]$. Lack of conditions for continuous (permanent) presence of dentists in specialized institutions as well as the difficulty in performing dental procedures in these patients is major problem. Dental treatment in these patients usually requires the involvement of a team of doctors, sometimes intervention under general anesthesia and of course the anesthesiologist [24]. Compromised oral health interferes normal functioning of mentally disabled persons because of difficulties in chewing, swallowing and speech [25]. Chronic and constant pain that sometimes exist in these patients is an additional problem and may further affect the psychosocial and emotional component of life of this population [26]. Caregivers or family members who take care of mentally impaired persons, very often due to lack of information give a little importance to the oral health. Therefore, various types of education and training in oral hygiene, good organization of health services, preventive measures and raising public health awareness in all segments of society can contribute to better quality of life in population with mental disability.

\section{CONCLUSION}

Clinically recorded poor oral health, poor mental state and significance of oral health on life quality of mentally disabled persons and persons dependent on someone's care, point out the necessity for systematic care for these patients. Good organization of health services and timely action based primarily on preventive and minimally invasive procedures is needed. It could be helpful to reduce the number of emergency interventions which are major stress for these patients but also for the dentist.

\section{REFERENCES}

1. World Health Organization. Active Ageing: A Policy Framework. Geneva: WHO; 2002.

2. Ebihara T, Yamaya M, Ohrui T, Arai H, Sasaki H. Comparison of disabled older people in the USA and Japan. Geriatr Gerontol Int. 2002; 2:53-6.
3. Caplan AL, McCartney JJ, Sisti DA. Health, Disease, and Illness: Concepts in Medicine. Washington, D.C.: Georgetown University Press; 2004.

4. Budtz-Jorgensen E. Prosthodontics for Elderly: Diagnosis and Treament. Chicago, IL: Quintessence; 1999.

5. Gajić M, Stevanović R. Hendikepirano dete u stomatološkoj ordinaciji. Čačak: Svetlost; 2002.

6. Mitsea AG, Karidis AG, Donta-Bakoyianni C, Spyropoulos ND. Oral health status in Greek children and teenagers with disabilities. I Clin Pediatr Dent. 2001; 26:111-8.

7. Budtz-Jørgersen E. Materials and methods for cleaning dentures. J Prost Dent. 1979; 42:619-23.

8. Nevalainen MJ, Närhi TO, Ainamo A. Oral mucosal lesions and oral hygiene habits in the home-living elderly. J Oral Rehabil. 1997; 24:332-7.

9. Batista LR, Moreira EA, Rauen MS, Corso AC, Fiates GM. Oral health and nutritional status of semi-institutionalized persons with mental retardation in Brazil. Res Dev Disabil. 2009; 30:839-46.

10. Hulland S, Sigal MJ. Hospital-based dental care for persons with disabilities: a study of patient selection criteria. Spec Care Dentist. 2000; 20:131-8.

11. Maureen LP, Monica AF. Oral health status of people with intellectual disabilities in the southeastern United States. J Am Dent Assoc. 2005; 136:903-12.

12. Jovanović S, Milovanović SD, Gajić I, Mandić J, Latas M, Janković Lj. Oral health status of psychiatric in-patients in Serbia and implications for their dental care. Croat Med J. 2010; 51:443-50.

13. Ramon T, Grinshpoon A, Zusman SP, Weizman A. Oral health and treatment needs of institutionalized chronic psychiatric patients in Israel. Eur Psychiatry. 2003; 18:101-5.

14. Velasco E, Machuca G, Martinez-Sahuquillo A, Rios V, Lacalle J, Bullon P. Dental health among institutionalized psychiatric patients in Spain. Spec Care Dentist. 1997; 17:203-6.

15. Angelillo IF, Nobile CG, Pavia M, De Fazio P, Puca M, Amati A. Dental health and treatment needs in institutionalized psychiatric patients in Italy. Community Dent Oral Epidemiol. 1995; 23:360-4.

16. Kumar M, Chandu GN, Shafiulla MD. Oral health status and treatment needs in institutionalized psychiatric patients: one year descriptive cross sectional study. Indian J Dent Res. 2006; 17:171-7.

17. Rodríguez Vázquez C, Garcillan R, Rioboo R, Bratos E. Prevalence of dental caries in an adult population with mental disabilities in Spain. Spec Care Dentist. 2002; 22:65-9.

18. Rekha R, Hiremath SS, Bharath S. Oral health status and treatment requirements of hospitalized psychiatric patients in Bangalore city: a comparative study. I Indian Soc Pedod Prev Dent. 2002; 20:63-7.

19. Lustig JP, Yanko R, Zilberman U. Use of dental implants in patients with Down syndrome: a case report. Spec Care Dentist. 2002; 22:201-4.

20. Lečić-Toševski D, Pejović-Milovančević M, Popović-Deušić S. Reform of mental health care in Serbia: ten steps plus one. World Psychiatry. 2007; 6:115-7.

21. Carević M. Primary dental health care in Serbia. Proceedings of the 15th Congress of the Balkan Stomatological Society; 2010 April 2225; Thessaloniki, Greece. Thessaloniki (Greece): Dental Schools of the Aristotle University; 2010.

22. Balogh RS, Ouellette-Kuntz H, Hunter DJ. Regional variation in dental procedures among people with an intellectual disability, Ontario, 1995-2001. J Can Dent Assoc. 2004; 70:681a-1681f.

23. Stanfield M, Scully C, Davison MF, Porter S. Oral healthcare of clients with learning disability: changes following relocation from hospital to community. Br Dent J. 2003; 194:271-7.

24. Pezzementi ML, Fisher MA. Oral health status of people with intellectual disabilities in the southeastern United States. J Am Dent Assoc. 2005; 136:903-12.

25. Gomes VN, Moreira Arantes Frigero ML, Fidelix M. Bone mass index analysis in elderly people before and after change prosthesis. Gerodontology. 2006; 23:187-91.

26. Davis DM, Fiske J, Scott B, Radford DR. The emotional effects of tooth loss: a preliminary quantitative study. Br Dent J. 2000; 188:503-6. 


\title{
Stanje zuba osoba s posebnim potrebama smeštenih u domu „Srce u jabuci” u Pančevu
}

\author{
Tatjana Savić-Stanković, Milica Jovanović-Medojević, Slavoljub Živković \\ Klinika za bolesti zuba, Stomatološki fakultet, Univerzitet u Beogradu, Beograd, Srbija
}

\begin{abstract}
KRATAK SADRŽAJ
Uvod Stanje zuba osoba s posebnim potrebama uglavnom nije zadovoljavajuće. Većina osoba je bez zuba ili s malim brojem zuba, ekstenzivnim akutnim karijesnim lezijama, visokim KEP indeksom i veoma izraženim oboljenjima potpornog aparata zuba. Cilj ovog rada je bio da se ispita stanje zuba osoba koje borave u domu za lica ometena u mentalnom razvoju „Srce u jabuci” u Pančevu.

Materijal i metode rada Klinička ispitivanja su obavljena na 114 ispitanika (68 muškaraca i 46 žena) starih od 22 do 71 godine. Ispitanici su svrstani u dve grupe, gde je prvu grupu činila 71 osoba umerenog stepena mentalnog oštećenja (F71), dok su drugu grupu činile 43 osobe s težim stepenom retardacije (F72). Stomatološkim pregledom su utvrđeni: broj zuba, postojanje karijesa, postojanje ispuna, broj izvađenih zuba, postojanje zaostalih korenova, fraktura, kao i postojanje i broj fiksnih nadoknada.

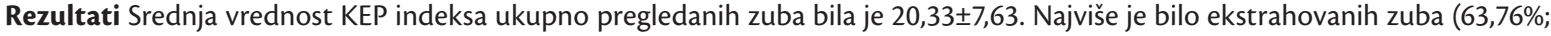
u prvoj grupi 63,23\%, u drugoj 64,06\%). Karijes je ustanovljen na trećini zuba (33,48\%), dok je plombiranih zuba bilo najmanje (2,76\%). Kod većine pregledanih osoba nisu uočeni ni inicijalni, ni duboki karijes, niti zubi s eksponiranom pulpom (K1 51,74\%; K2 40,35\%; K3 51,75\%). Više od deset izvađenih zuba imalo je 52,63\% ispitanika. Najveći broj ispitanika nije imao nijedan ispun u ustima (81\%), a samo tri osobe su imale fiksne nadoknade.

Zaključak Stanje zuba osoba smeštenih u specijalizovanoj ustanovi za lica ometena u mentalnom razvoju ukazuje na visok procenat ekstrahovanih zuba, značajne karijesne lezije i mali procenat plombiranih zuba, uz neodgovarajuću oralnu higijenu.
\end{abstract}

Ključne reči: osobe ometene u razvoju; karijes; ekstrakcija; plomba

\section{UVOD}

Ako je, prema definiciji, zdravlje stanje potpunog fizičkog, mentalnog i socijalnog blagostanja, a ne samo izostanak bolesti i onesposobljenosti [1], onda se kod osoba ometenih u mentalnom razvoju ne može govoriti o potpunom zdravlju, jer je oralno zdravlje kod njih uglavnom zapostavljeno. Mentalno hendikepirane osobe, koje su najčešće, zbog poremećenog rasuđivanja i razumevanja i nesamostalnosti, smeštene u specijalizovane ustanove, zahtevaju posebnu pažnju i brigu u svakom smislu, a posebno u pogledu očuvanja oralnog zdravlja. Nažalost, najveći broj ovih osoba je često bez zuba ili s malim brojem zuba, s ekstenzivnim akutnim karijesima, visokim KEP indeksom i izraženim oboljenjima potpornog aparata zuba [2]. Na ovaj problem utiču razni faktori, a jedan od osnovnih je to što u takvim ustanovama obično nema stomatologa koji bi brinuo o njihovom oralnom zdravlju, ali i predrasuda brojnih stomatologa o teškoćama izvođenja stomatoloških pregleda i lečenja kod takvih pacijenata. S druge strane, ove osobe često odbijaju pomoć u sanaciji zuba, pa su onda intervencije kod njih uglavnom hitne i bolne.

Oralno zdravlje ima veliki uticaj na svakodnevno funkcionisanje i kvalitet života mentalno ometenih osoba, s obzirom na to da je ono obično dodatno narušeno usled oboljenja drugih sistema i organa [3]. U sporedne efekte različitih terapijskih postupaka i lekova koji se često daju ovim pacijentima ubraja se i povećan rizik od oralnih oboljenja, koja nastaju usled smanjenog lučenja pljuvačke, upale desni, resorpcije alveolarne kosti i mobilnosti zuba [4]. Ne treba isključiti ni činjenicu da većina ovih osoba prima analgetsku terapiju, pa bola, kao upozoravajućeg faktora da se nešto dešava sa zubima, uglavnom nema.

Jedan od načina sanacije zuba osoba ometenih u mentalnom razvoju (pogotovo težih stepena retardacije) jeste i mogućnost obavljanja stomatoloških intervencija u opštoj anesteziji. Time se pacijentu i terapeutu olakšava postupak, ali i obezbeđuje pravilna, detaljna i kompletna stomatološka zaštita [5].

Podizanje nivoa oralnog zdravlja kod osoba ometenih u metalnom razvoju može se uspešno postići pravilnim pristupom, primenom postupaka i mera prevencije i kontinuiranim praćenjem stanja njihovih usta i zuba. Obukom pomoćnog osoblja, negovatelja, o pravilnom načinu i merama održavanja oralne higijene, odnosno njihovom pravilnom izvođenju, može se uspešno poboljšati stanje oralnog zdravlja ovih pacijenata. Činjenica je takođe da se epidemiološka istraživanja čiji je cilj utvrđivanje nivoa oralnog zdravlja stanovništva, primene mera prevencije, funkcionisanja i efikasnosti stomatološke zdravstvene službe uglavnom izvode u mlađoj populaciji. Realizacija ovakvih istraživanja kod starijih ljudi, pogotovo kod osoba s posebnim potrebama, izuzetno su retka, te su i podaci u literaturi uglavnom vrlo oskudni.

Cilj ovog rada je bio da se utvrdi stanje usta i zuba, odnosno potreba za stomatološkim lečenjem osoba smeštenih u specijalizovanoj ustanovi za negu osoba ometenih u mentalnom razvoju.

\section{MATERIJAL I METODE RADA}

Klinička ispitivanja su obavljena na 114 štićenika doma za mentalno hendikepirane osobe „Srce u jabuci” u Pančevu (68 muškaraca i 46 žena) starih od 22 do 71 godine. U zavisnosti od stepena mentalnog oštećenja, prema Desetoj reviziji Međunarodne klasifikacije bolesti (MKB-10), ispitanici su svrstani u dve grupe. Prvu grupu je činila 71 osoba umerenog stepena mentalnog oštećenja (F71), dok su drugu grupu činila 43 ispitanika s težim stepenom retardacije (F72).

Analiza stanja zuba je izvršena pomoću stomatološkog ogledalceta, stomatološke prave i aproksimalne i parodontološke sonde. Pregledom su utvrđeni i upisani u stomatološke kartone za 
svakog pacijenta posebno sledeći podaci: broj zuba, postojanje karijesa, postojanje ispuna (amalgamskih i estetskih), broj izvađenih zuba, postojanje zaostalih korenova $(\mathrm{R})$, fraktura $(\mathrm{F}) \mathrm{i}$ fiksnih nadoknada (FN).

Prevalencija karijesa je određena pomoću KEP indeksa i njegovih komponenti na sledeći način: K1 - inicijalni karijes (karijes u gleđi), K2 - duboki karijes (karijes dentina), K3 - eksponirana pulpna komora, I - ispuni, E - ekstrahovani zubi. Zaostali korenovi i frakture su analizirani kao potkomponente karijesa.

\section{REZULTATI}

Srednja vrednost KEP indeksa ukupno pregledanih zuba bila je 20,33 $\pm 7,63$, a po grupama ispitanika $19,96 \pm 7,11$ (prva) i $20,95 \pm 8,47$ (druga). Najviše je bilo ekstrahovanih zuba - 63,76\%, zuba zahvaćenih karijesom bilo je 33,48\%, dok je najmanje bilo plombiranih zuba - 2,76\% (Tabela 1 ).

Analizom učestalosti komponenata KEP uočena je statistički značajna razlika između broja ekstrahovanih i zuba zahvaćenih karijesom, odnosno plombiranih zuba $(\mathrm{t}=2,06$; $\mathrm{p}<0,005)$. Statistički značajne razlike nije bilo u broju inicijalnih karijesa (K1), dubokih karijesa (K2) i zuba s eksponiranom pulpom (K3) (Tabela 1).

U tabeli 2 prikazan je broj ekstrahovanih zuba kod pregledanih osoba. Najveći broj ispitanika imao je više od deset ekstrahovanih zuba (52,63\%). Bez ekstrahovanih zuba bilo je 2,63\% osoba. U prvoj grupi više od deset ekstrahovanih zuba imalo je $52,11 \%$ ispitanika, a u drugoj grupi 53,49\%.

U tabeli 3 prikazana je distribucija inicijalnog karijesa (K1) kod pregledanih pacijenata. Kod većine on nije ustanovljen $(51,74 \%)$, a nalaz je bio sličan u obe grupe ispitanika $(52,11 \%$ u prvoj i 51,16\% u drugoj).

U tabeli 4 prikazana je distribucija dubokog karijesa (K2), koji kod većine ispitanika nije ustanovljen (40,35\%). U prvoj grupi je uočen podjednak broj ispitanika bez karijesa i onih s jednim dubokim kvarom zuba (29,58\%), dok u drugoj grupi najveći procenat pregledanih pacijenata nije imao nijedan duboki kvar na zubima $(58,14 \%)$.

U tabeli 5 prikazana je distribucija eksponirane pulpe (K3) kod pregledanih pacijenata. Kod većine ispitanika ona nije ustanovljena (51,75\%), a slični rezultati su zabeleženi u prvoj $(49,30 \%)$, odnosno u drugoj grupi $(55,81 \%)$.

Najveći broj pregledanih osoba - $81 \%$ - nije imao nijedan ispun u zubima. Po jedan ispun imalo je $6 \%$ ispitanika, dva ili tri ispuna $9 \%$, a više od četiri ispuna $4 \%$ pacijenata.

Čak 111 ispitanika nije imalo nijednu fiksnu nadoknadu. Samo jedan pacijent je imao jednu fiksnu nadoknadu, dok su dve fiksne nadoknade utvrđene kod dva ispitanika.

\section{DISKUSIJA}

Loše stanje usta i zuba osoba ometenih u mentalnom razvoju uglavnom je očekivano zbog teškog opšteg stanja ovih pacijenata, ali i čestog zanemarivanja ovog aspekta njihovog zdravlja. Ove osobe, zbog hendikepa, nisu sposobne da samostalno brinu o adekvatnom održavanju higijene usta i zuba, što se vremenom odražava i na opšte stanje oralnog zdravlja. Problem održavanja oralne higijene posledica je smanjenog, a nekada i potpunog, nedostatka mišićne koordinacije pokreta, odnosno nemogućnosti razumevanja i praćenja uputstava i saveta u vezi s merama prevencije [6]. Činjenica da je pravilno svakodnevno održavanje oralne higijene jedan od najvažnijih faktora prevencije nastanka oboljenja usta i zuba značajan je preduslov razvoja, ali i brzog napredovanja već narušenog oralnog zdravlja kod ovih osoba, koje najčešće borave u ustanovama specijalizovanim za brigu o licima s posebnim potrebama $[7,8]$.

KEP indeks je jedan od najčešće primenjivanih parametara u epidemiološkim studijama koji se koristi za predstavljanje stanja zuba, tačnije incidencije zuba zahvaćenih karijesom, ekstrahovanih i plombiranih zuba $[9,10]$. Rezultati našeg istraživanja su pokazali visoke srednje vrednosti ovog indeksa $(20,95 \pm 8,47)$. One se mogu tumačiti, pre svega, teškim opštim stanjem ovih pacijenata, te nisu posledica samo nesposobnosti i nesamostalnosti, nego i činjenice da ovi pacijenti nemaju odgovarajuću stomatološku zaštitu i da se loše oralno zdravlje ne rešava pravovremeno.

Osobe s težim stepenom poremećaja psihofizičkog razvoja neretko pored mentalnih imaju i teže poremećaje motorike, i u većini slučajeva su teško pokretni, a često čak i potpuno nepokretni [6]. Razlike u vrednosti KEP indeksa između prve i druge grupe bile su neznatne, jer su osobe smeštene u pomenutom domu (čak i one s većim stepenom mentalne ometenosti) prilično socijalizovane i znatno samostalnije od onih koje ne žive u ustanovama ovoga tipa. Podaci iz literature govore da su vrednosti KEP indeksa kod ovih pacijenata u Sjedinjenim Američkim Državama 13,6, a u zapadnoevropskim zemljama 15,85 , što nedvosmisleno upućuje na to da razvoj zemlje, odnosno regiona može biti jedan od glavnih faktora stanja oralnog zdravlja [11]. Nažalost, malo je dostupnih podataka o istraživanjima iz ove oblasti i u regionu, Evropi, pa i svetu, te je poređenje ovih rezultata s nalazima sličnih istraživanja teško.

Rezultati našeg istraživanja i vrednost KEP indeksa od 24,4 delimično su saglasni s nalazima ispitivanja psihijatrijskih bolesnika smeštenih u Specijalnoj bolnici za psihijatrijske bolesti „Dr Laza Lazarević” u Beogradu, iako psihičko stanje ovih pacijenata nije baš slično [12]. Ramon (Ramon) i saradnici [13], Velasko (Velasco) i saradnici [14] i Angeliljo (Angelillo) i saradnici [15] takođe su ukazali na slične vrednosti KEP indeksa kod psihijatrijskih bolesnika $(26,74 ; 24,99 ; 15,5)$. Rezultati Kumara (Kumar) i saradnika [16], u kojima je srednja vrednost KEP indeksa 0,92 , značajno se razlikuju od ovih i tumače činjenicom da se pijaća voda u oblasti u kojoj se nalazi specijalizovana ustanova čiji su štićenici ispitani obogaćuje fluorom.

Rezultati našeg istraživanja takođe nisu u skladu s nalazima Rodriges Vaskesa (Rodríguez Vázquez) i saradnika [17], koji su u svojoj studiji ispitali osobe s mentalnim oštećenjima. Kod bolesnika sa Daunovim sindromom srednja vrednost KEP indeksa bila je 3,97, kod bolesnika s cerebralnom paralizom 6,56, a kod ispitanika s idiopatskim razvojnim poremećajima 7,36. Ovako male vrednost KEP indeksa autori tumače činjenicom da je reč o hospitalizovanim pacijentima čija je ishrana pod stalnom kontrolom, uključujući i kontrolu nivoa šećera u hrani.

Analiza komponenti KEP indeksa pokazuje da su kod ispitanika našeg istraživanja najčešći bili ekstrahovani zubi. Naime, čest izostanak bola usled kontinuiranog analgetičkog dejstva lekova, otežana saradnja, nepostojanje stalnog stomatološkog nadzora i uglavnom zakasnele stomatološke intervencije osnovni su razlog velikog broja ekstrahovanih zuba kod naših 
ispitanika. Ovi razlozi takođe objašnjavaju činjenicu da najveći broj pacijenata nije imao nijedan početni karijes, duboki karijes ili eksponiranu pulpu. Naime, brz, iznenadan i snažan tok karijesnih lezija kod osoba sa neadekvatnom oralnom higijenom brzo dovodi do gubljenja zuba. Naše istraživanje pokazuje da je u pogledu komponenata KEP indeksa najmanje ispitanika imalo plombirane zube. Ovo je u skladu s malim procentom karijesnih lezija, otežanom saradnjom s ovim pacijentima, ali i izostankom pravovremene stomatološke zaštite i brige o njihovom oralnom zdravlju [18].

Samo tri ispitanika od 114 imala su fiksne zubne nadoknade. Ovaj podatak pokazuje da je složene stomatološke intervencije (koje zahtevaju više poseta stomatologu i dobru saradnju) moguće realizovati samo u posebnoj ustanovi (ordinaciji) i uz povećanu brigu i angažman osoblja iz ustanove, odnosno članova porodice pacijenta. Uz trud i napor svih koji pripadaju sistemu nege osoba ometenih u razvoju, kod ovakvih pacijenata moguća je protetička sanacija i ugradnjom proteza [19].

Srbija je jedna od nekoliko zemalja u svetu koje nemaju potpune podatke o stanju oralnog zdravlja svog stanovništva [20]. Skorašnja reforma zdravstvenog sistema u većini balkanskih zemalja, posebno onih koje prolaze kroz političku i ekonomsku tranziciju, gotovo potpuno je isključila stomatologiju iz primarnog zdravstvenog sistema. Posledica toga je prebacivanje zdravstvene zaštite na privatni sektor, koji takođe uključuje brojne probleme, a samim tim i neadekvatnu dostupnost i gubitak uvida u podatke o oralnom zdravlju kako stanovništva u celini, tako i osoba ometenih u mentalnom razvoju. Da bi se problem rešio, početkom 2009. godine u Srbiji je usvojen Nacionalni program prevencije oralnih oboljenja [21].

Strana literatura koja se bavi oralnim zdravljem osoba ometenih u mentalnom razvoju neprestano ukazuje na loše stanje njihovih usta i zuba, veliki broj ekstrahovanih zuba i mali broj ispuna $[22,23]$. Nepostojanje uslova za stalno prisustvo stomatologa u specijalizovanim ustanovama i teškoće izvođenja stomatoloških zahvata kod pacijenata koji borave u ovim institucijama predstavljaju velike probleme, jer izvođenje ovakvih intervencija, od kojih se neke izvode u opštoj anesteziji bolesnika, zahteva angažovanje tima lekara, među kojima treba da bude i anesteziolog [24]. Ugroženo oralno zdravlje i funkcionisanje osoba ometenih u mentalnom razvoju znatno otežavaju i žvakanje, gutanje i govor [25]. Hronični bolovi kod ovih pacijenata dodatni su problem koji može uticati na psihosocijalnu i emotivnu komponentu njihovog života [26]. Negovatelji ili članovi porodice koji se brinu o osobama ometenim u mentalnom razvoju često zbog neinformisanosti pridaju malo značaja njihovom oralnom zdravlju. Zato razni vidovi edukacije, obuke u održavanju oralne higijene, dobra organizacija zdravstvene službe, mere prevencije i podizanje opšte zdravstvene svesti u svim segmentima društva mogu doprineti kvalitetnijem životu i osoba s problemima u razvoju.

\section{ZAKLJUČAK}

Klinički potvrđeno loše stanje usta i zuba, loše psihičko stanje i veliki uticaj stanja oralnog zdravlja na kvalitet života osoba ometenih u mentalnom razvoju, koje su zavisne od tuđe nege i pomoći, pokazuju da je ove pacijente neophodno sistemski zbrinjavati. Potrebni su dobra organizacija zdravstvene službe i pravovremeno delovanje, kako bi stomatološka sanacija mogla da se primeni u vidu preventivnih i minimalno invazivnih zahvata. Tako se može smanjiti broj hitnih intervencija, koje su veliki stres za ove pacijente, ali i za stomatologa. 